Gut, 1961, 2, 338

\title{
The effect of corticotrophin and corticosteroids on the external secretion of the pancreas in dogs
}

\author{
WILFRED SIRCUS ${ }^{1}$ \\ From the Department of Medicine, the University of Edinburgh, and the \\ Gastrointestinal Unit, the Western General Hospital, Edinburgh
}

SYNOPSIS In acute experiments in dogs cortisone and hydrocortisone increase the concentration and output of bicarbonate in pancreatic secretion whereas prolonged administration of these hormones leads to a diminished bicarbonate response. In both acute and chronic experiments, however, cortisone and hydrocortisone produce an increased output of the enzymes amylase and trypsin.

There are several published reports of the effect of corticotrophin and corticosteroids on gastric secretion in man and other species but only two, both in man, concerning their effect upon pancreatic secretion. Pfeffer and Hinton (1956) stimulated the pancreas with intravenous secretin and insulin after prior injection or infusion of hydrocortisone and corticotrophin. Dreiling, Janowitz, and Rolbin (1958) injected secretin, collected the duodenal contents for a subsequent period of 80 minutes and then, after injecting either corticotrophin, hydrocortisone, or prednisolone, continued duodenal aspiration for a further five hours. Amylase was the only enzyme determined in each study. In another paper Dreiling and Janowitz (1959) further analysed the data from their original work. Both groups of workers concluded that corticotrophin and corticosteroids depressed the production of bicarbonate and Dreiling et al. found a similar effect on amylase. The present study was begun for two reasons : first, to examine the effects of corticotrophin and corticosteroids on pancreatic secretion under more exact conditions in the dog, and secondly, to gain more knowledge concerning the degree of tissue specificity involved in such actions of corticosteroids as the known one on gastric secretion.

The mode of action of corticotrophin and corticosteroids on the parietal cells of the stomach, or, indeed, on any glandular tissue, is uncertain. There is evidence that steroids may affect the d-amino acid oxidase enzyme involved in intracellular processes of oxidation and reduction (Hayano and Dorfman, 1951; Umbreit, 1951). It is

'Part-time member of the external staff of the Medical Research Council. arguable that if the action on gastric secretion is effected by influencing intracellular metabolism then it should be as readily demonstrable in other glandular structures of the alimentary tract with exocrine function, including the pancreas.

METHOD

Two dogs were prepared for investigation of the effects of long-term administration of hormones by the formation of an exteriorized loop of duodenum. At operation the pancreatic accessory duct was found and divided between ligatures. The duodenum was transected immediately proximal to the main pancreatic duct and the proximal portion anastomosed, end to side, to the fourth part of the duodenum to restore alimentary continuity. The free end distal to the transection was closed and brought out of the abdominal cavity and permanently exteriorized outside the recti muscles which were closed together in the usual manner. A previously prepared skin flap was then sewn around the exteriorized duodenal loop to form a 'suitcase handle'. A silver cannula with a screw cap was inserted into the anti-mesenteric border of the loop immediately opposite the main pancreatic duct (Fig. 1). Pancreatic secretion was subsequently collected by placing a non-traumatic clamp across the skincovered loop immediately distal to the cannula. A small closed chamber of about $2 \mathrm{~cm}$. diameter was thus formed around the main duct, and, in the erect position of the dog, uncontaminated pancreatic juice flowed down the cannula from which the cap had been unscrewed.

In three other dogs after likewise dividing the accessory pancreatic duct a double or jacketed silver cannula (Fig. 2) was inserted into the duodenum opposite to the main duct opening. The duodenum was not otherwise disturbed. Recovery of pancreatic juice was obtained by advancing the inner tube until the conical flange at the 


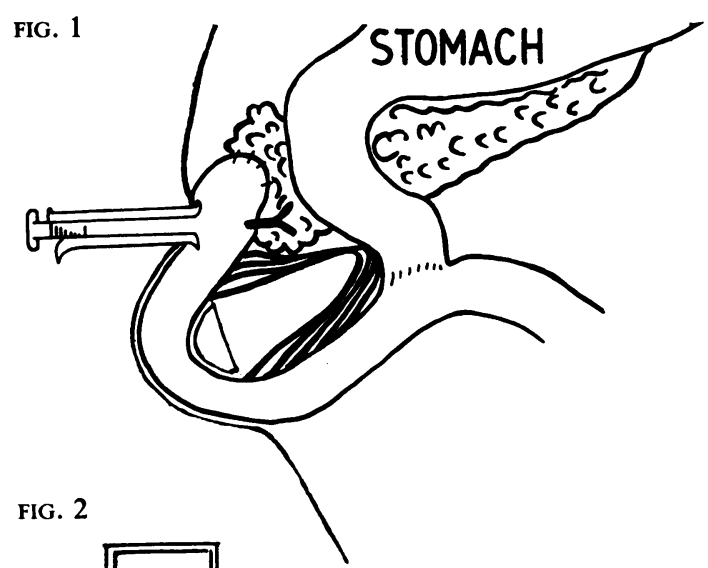

FIG. 1. Skin-covered, exteriorized, cannulated duodenal loop for collecting pancreatic secretion.

FIG. 2. A double cannula for direct collection of secretion from the main pancreatic duct. end impinged on the duodenal wall around the main duct opening and thus isolated it.

In all experiments the pancreatic secretion was collected under glycerol and in a container surrounded by ice.

Amylase was determined by a modification of the method of Lagerlöf (1942), trypsin according to the method of Gowenlock (1953) and expressed as Gowenlock units, and lipase by the method described by Sammons, Frazer, and Thompson (1956), using olive oil as the substrate.

\section{PROCEDURES}

EFFECT OF LONG-TERM ADMINISTRATION OF CORTISONE Two dogs were used and six control experiments made on each to determine the normal response to the intravenous injection of secretin and pancreozymin.

Cortisone (cortisone acetate, Glaxo), either 25 or $50 \mathrm{mg}$., was given orally each day for 53 days to one dog and for 120 days to the other, and the test procedure repeated at intervals. Secretin and pancreozymin (Boots) were given intravenously in a dose of 2 units $/ \mathrm{kg}$. body weight. This dose was found to produce the maximum response from the pancreas under normal conditions. The design of the experiment was to collect fasting pancreatic juice for 15 minutes, then secretin was injected, and the response collected for 30 minutes. At the end of that time the pancreozymin was injected and the secretion collected for a further $\mathbf{3 0}$ minutes.

EFFECT OF LONG-TERM ADMINISTRATION OF CORTICOTROPHIN This study was carried out on one dog. Control experiments were made to establish the pancreatic secretory response to a standardized meal and to secretin and pancreozymin.

Eight ounces of a proprietary food (Lassie) were fed and pancreatic secretion continuously collected for three hours. Tins of food from the same batch of manufacture were used throughout.

The stimulating procedures were repeated at intervals after beginning the daily intramuscular injection of 40 units of corticotrophin.

A capsule containing $1 \mathrm{~g}$. of potassium chloride was fed each day to the dogs in both groups.

EFFECT OF SINGLE INJECTIONS OF HYDROCORTISONE Three dogs were used to test the effect of single injections of hydrocortisone on the pancreatic response to secretin and pancreozymin.

Injection of hydrocortisone during continuous infusion of hormones Secretin or pancreozymin was infused intravenously using a motor-driven continuous infusion apparatus (Palmer). When the volume output of the pancreatic response had reached a plateau, $100 \mathrm{mg}$. of hydrocortisone hemisuccinate sodium (Glaxo) was injected intravenously.

Administration of hydrocortisone before injection of secretin and pancreozymin One hundred milligrams of hydrocortisone hemisuccinate sodium were injected intravenously either 15 or 30 or 60 minutes before the intravenous injection of secretin and pancreozymin in 

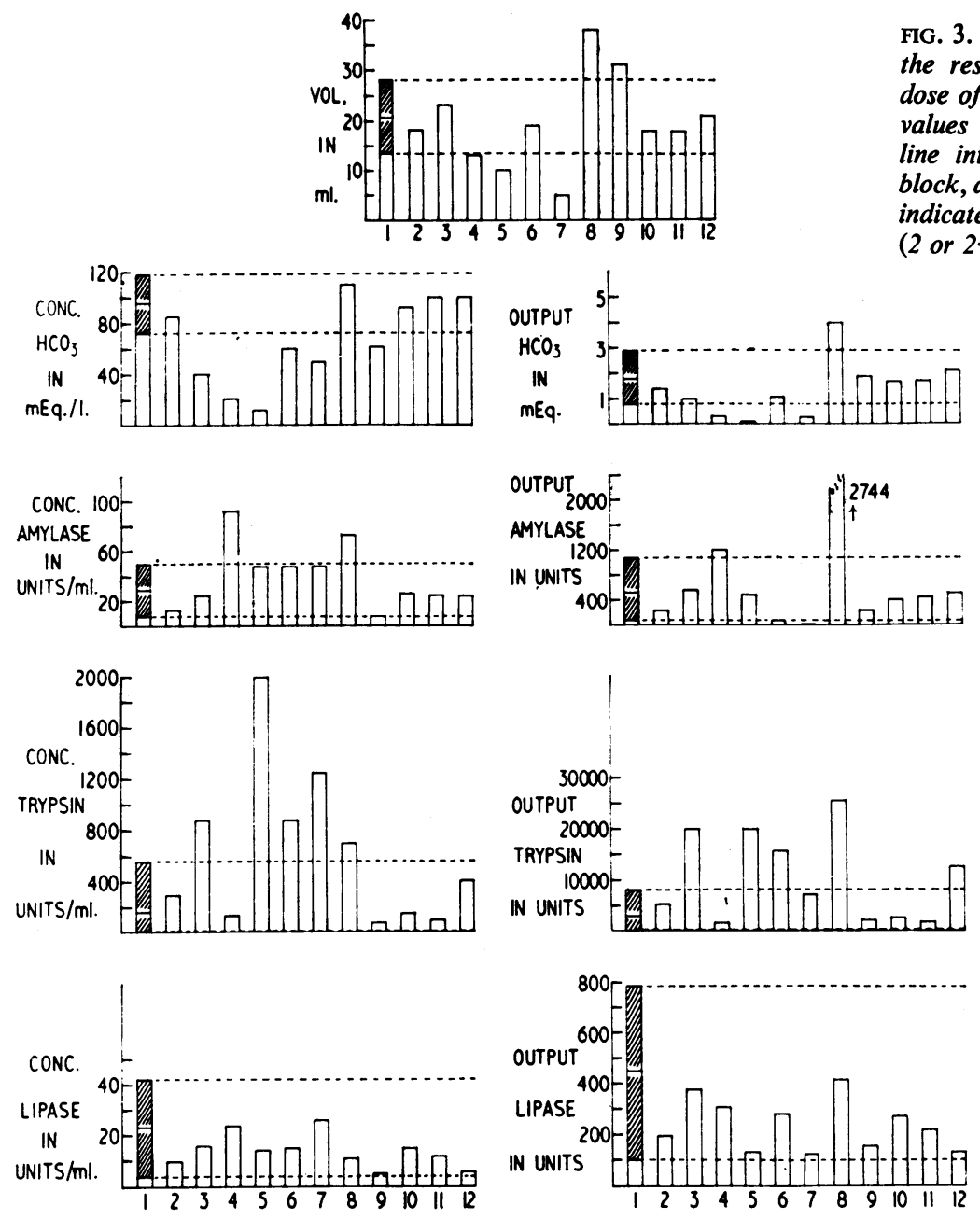

BLOCK NOS

$\begin{array}{lccccccccccccc} & \overbrace{1} & 2 & 3 & 4 & 5 & 6 & 7 & 8 & 9 & 10 & 11 & 12 \\ \text { DANS ON CORTISONE } & 0 & 19 & 26 & 34 & 48 & 57 & 62 & 70 & 79 & 86 & 93 & 126 \\ \text { CUMULATIVE DOSE (mg.) } & 0 & 500 & 850 & 1250 & 1950 & 2400 & 2650 & 3050 & 3500 & 3850 & 4200 & 4725\end{array}$

the standard test detailed above and the results compared with control experiments, omitting the hydrocortisone.

\section{RESULTS}

In the text, results are only considered to be significant when they differ from the control values by more than two standard deviations.

EFFECT OF PROLONGED ADMINISTRATION OF CORTISONE ON RESPONSE TO SECRETIN In dog $F$ there were considerable variations in the results over the whole period of cortisone administration but a striking difference appeared between the effects on electrolytes and enzymes. The concentration and output of
FIG. 3. Dog $F$. The effect of cortisone on the response to a standard intravenous dose of secretin. The mean of the control values is represented by the horizontal line interrupting the cross-hatched first block, and the extent of the cross-hatching indicates the 1 in 40 confidence limits ( 2 or $2.5 \%$ probability value). bicarbonate tended to fall whereas the concentration and output of trypsin tended to rise. These effects were most evident during the second and third months of administration. Significant increases in volume appeared episodically and in two tests the concentration and output of amylase were raised. The concentration and output of lipase were unaffected throughout (Fig. 3).

In $\operatorname{dog} \mathrm{E}$, only four experiments were made after beginning the administration of cortisone. The output of bicarbonate was again found to be reduced but no significant changes appeared in the concentration and output of the enzymes by the fifty-third day, soon after which the dog died from 

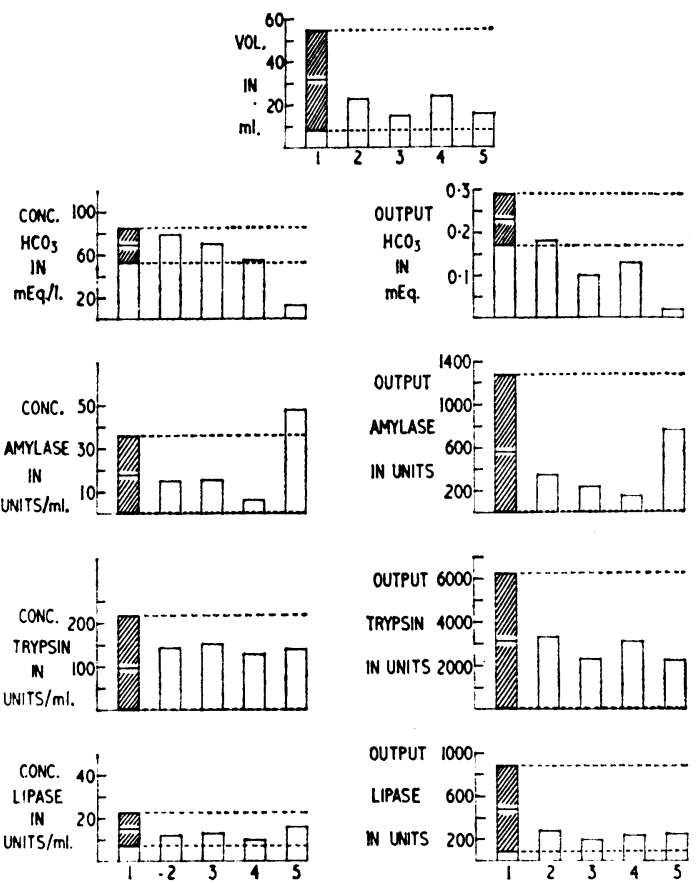

\begin{tabular}{lccccc} 
& \multicolumn{4}{c}{} & \multicolumn{4}{c}{ BLOCK NOS } \\
DAYS ON CORTISONE & 0 & 3 & 4 & 5 \\
CUMULATINE DOSE (mg.) & 0 & 250 & 600 & 750 & 1200
\end{tabular}

FIG. 4. Dog E. The effect of cortisone on the response to a standard intravenous dose of secretin. The mean of the control values is represented by the horizontal line interrupting the cross-hatched first block, and the extent of the cross-hatching indicates the 1 in 40 confidence limits ( 2 or $2.5 \%$ probability value).

a perforation of the duodenum caused by pressure necrosis from the cannula (Fig. 4).

EFFECT OF PROLONGED ADMINISTRATION OF CORTISONE ON RESPONSE TO PANCREOZYMIN In $\operatorname{dog} F$, there again appeared significant effects upon the bicarbonate and trypsin components of the secretion and also upon the volume output.

The volume was raised in the second and third months of the tests, as was both concentration and output of trypsin. Although the concentration of bicarbonate was lowered in many tests the increase in volume output caused an increase in bicarbonate output on four occasions. Furthermore in most of the tests the output of amylase was significantly raised.

The output of lipase was unaffected in all but two tests, in which it was raised, as a result of increases in volume output (Fig. 5).

In $\operatorname{dog} E$, the only significant changes in the few available results show a reduction in concentration and output of bicarbonate and a rise in concentration and output of amylase and trypsin (Fig. 6). There were no changes noted in the lipase response.

EFFECT OF PROLONGED ADMINISTRATION OF CORTICOTROPHIN IN RESPONSE TO A MEAT MEAL The volume output was significantly reduced after the administration of corticotrophin. Changes otherwise appeared only in the bicarbonate response in which the concentration was reduced in half the experiments and the output in all. No significant changes were noted in the concentrations and outputs of the three enzymes (Fig. 7).

EFFECT OF PROLONGED ADMINISTRATION OF CORTICOTROPHIN ON RESPONSE TO SECRETIN AND PANCREOZYMIN The results of only three experiments were available and demonstrated a reduction in the volume output, and the concentrations and outputs of bicarbonate, trypsin, and amylase. The concentration and output of lipase was unaffected.

EFFECT OF HYDROCORTISONE ON RESPONSE TO A CONTINUOUS INFUSION OF SECRETIN Five experiments were made on three dogs.

In four an increase in the volume output appeared within five minutes and persisted for up to one hour. The mean increase was approximately $50 \%$ above the maximum obtained before the injection of hydrocortisone. The output of bicarbonate and amylase was increased in four experiments and the concentrations in three. In the two experiments in which trypsin was estimated the concentration and output were unaffected. Lipase was estimated in only one experiment and the output rose substantially after the injection of hydrocortisone (Fig. 8).

EFFECT OF HYDROCORTISONE ON RESPONSE TO A CONTINUOUS INFUSION OF PANCREOZYMIN Four experiments were made on three dogs.

The results were more variable than those obtained on the response to secretin.

The volume output and the concentrations and outputs of bicarbonate, amylase, and trypsin were all increased in two experiments, reduced in one, and unchanged in the other.

An experiment is illustrated in which an increased response followed the injection of hydrocortisone (Fig. 9).

EFFECT OF PRIOR INJECTION OF HYDROCORTISONE UPON THE RESPONSE TO SINGLE INJECTIONS OF THE PANCREATIC HORMONES Hydrocortisone, $100 \mathrm{mg}$., was injected intravenously 10 to 15 minutes before 

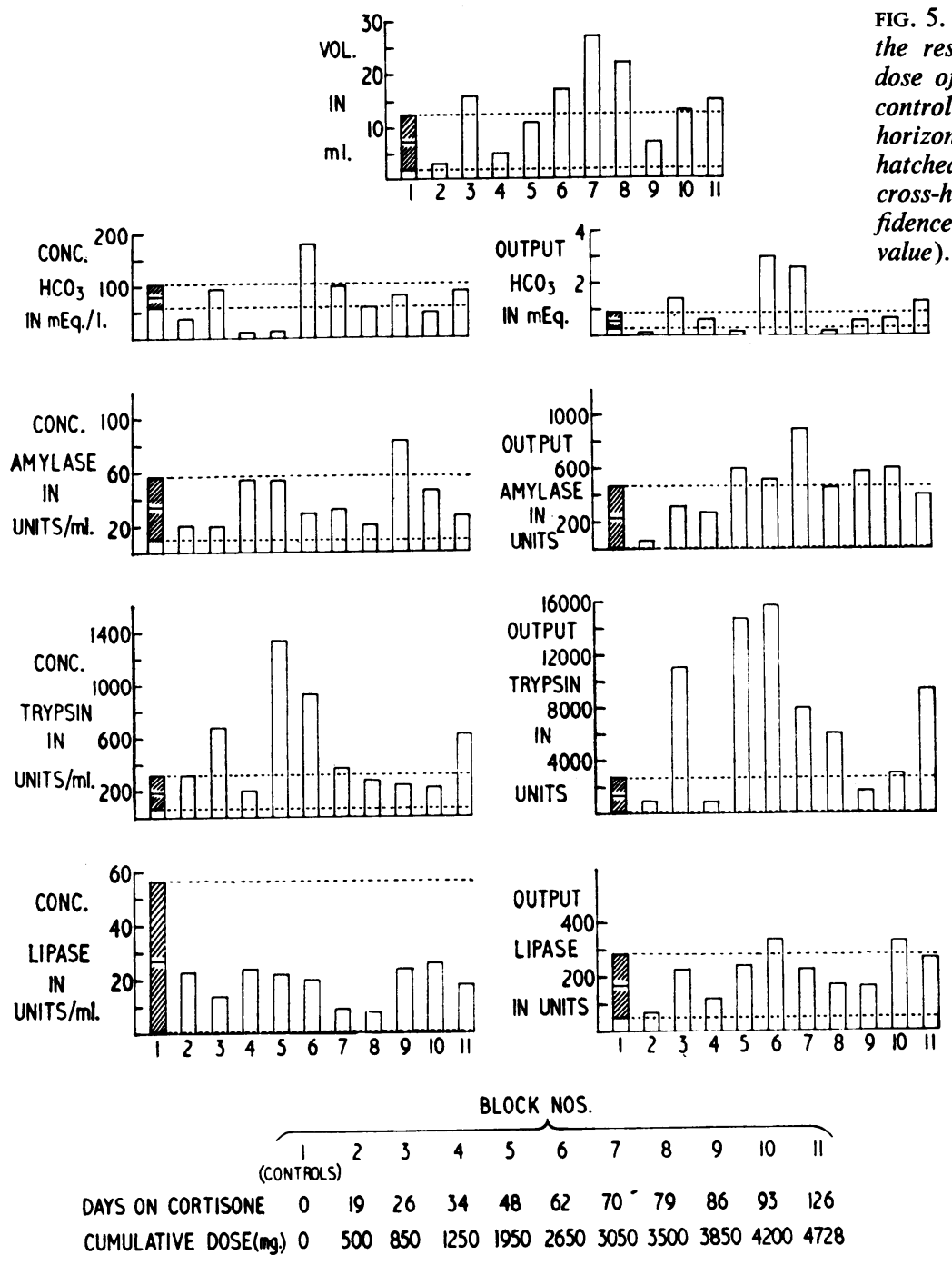

injecting secretin or pancreozymin. Two experiments were made with each hormone in two dogs, and in all four there appeared a substantial increase in the concentration and output of bicarbonate and amylase (Figs. 10 and 11). The other enzymes were not determined in this group of experiments.

The effect of injecting hydrocortisone 30 minutes before secretin and 60 minutes before pancreozymin was tried. Seven control experiments determined the standard response. Two experiments were made with each hormone after the administration of the steroid. In none of the four experiments was any effect noted upon volume, concentration, or output of bicarbonate, amylase, lipase, and trypsin.

In most of the experiments in which an increased volume response was obtained there also appeared an
FIG. 5. Dog F. The effect of cortisone on the response to a standard intravenous dose of pancreozymin. The mean of the control values is represented by the horizontal line interrupting the crosshatched first block, and the extent of the cross-hatching indicates the 1 in 40 confidence limits (2 or $2.5 \%$ probability value ).

increase in the concentrations of the bicarbonate and enzymes. Thus the augmentation of output after hydrocortisone is unlikely to be the result of an increased 'washing-out' effect of enzymes from the duct system.

\section{DISCUSSION}

The results clearly indicate that the pancreatic response, both of electrolytes and enzymes, to stimulation by meals, secretin, and pancreozymin can be influenced by corticotrophin and steroids.

The depression of pancreatic secretion after corticotrophin was noted in a single dog but the result confirms the observations of Pfeffer and Hinton and Dreiling et al. previously quoted. In 

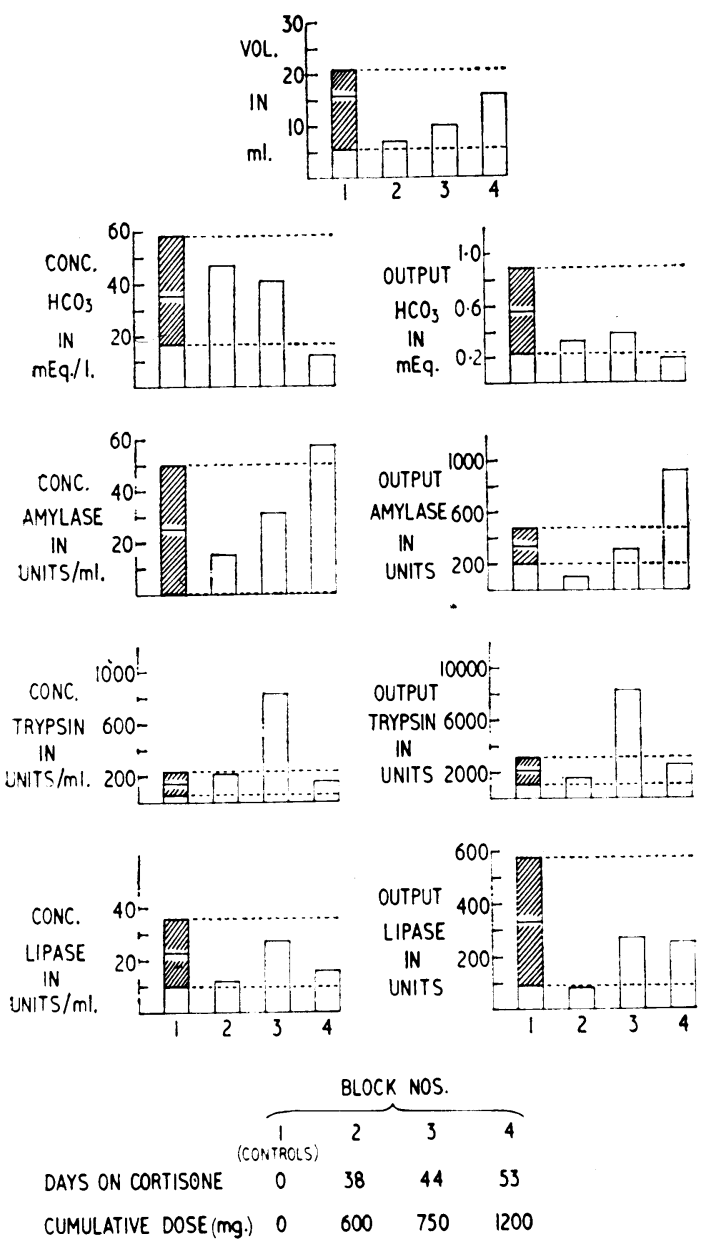

FIG. 6
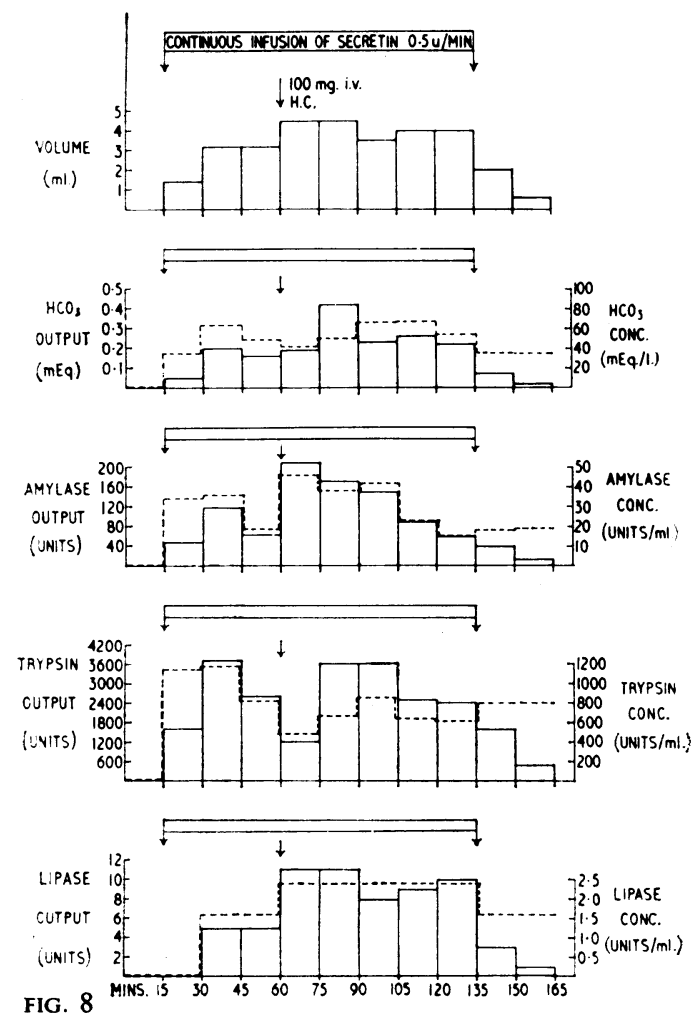
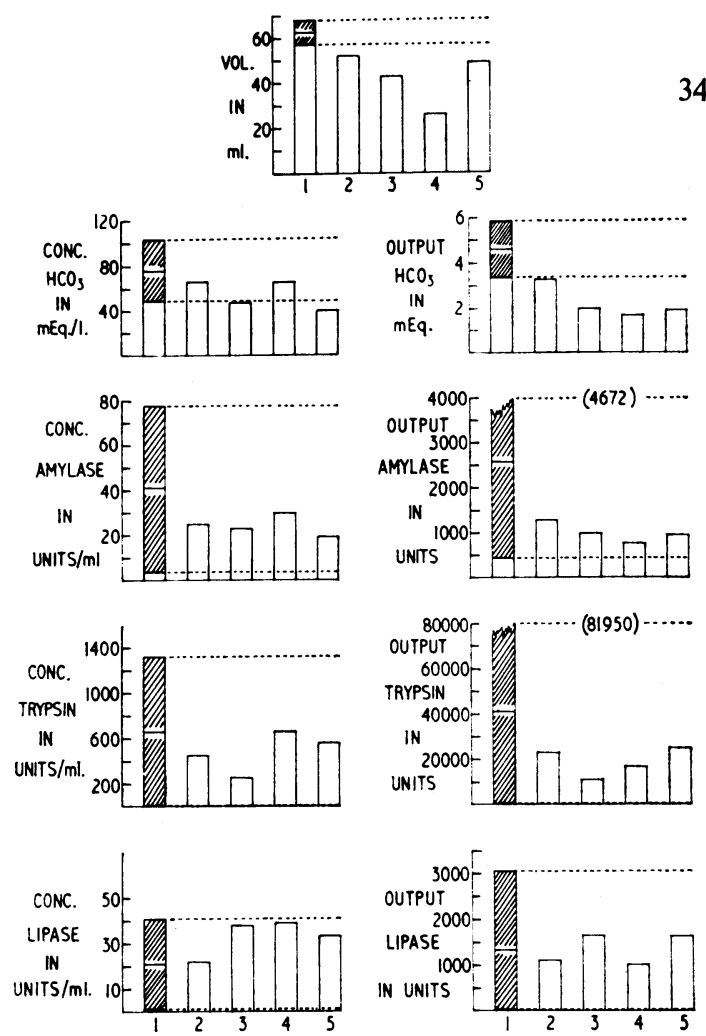

$$
\begin{array}{ccccccc}
\cline { 2 - 6 } & \multicolumn{4}{c}{\text { BLOCK NOS. }} \\
\cline { 2 - 6 } \text { DAYS ON ACTH } & 0 & 2 & 3 & 4 & 5 \\
\text { CUMULATIVE DOSE (UNITS) } & 0 & 480 & 800 & 1600 & 1920
\end{array}
$$

FIG. 7

FIG. 6. Dog E. The effect of cortisone on the response to a standard intravenous dose of pancreozymin. The mean of the control values is represented by the horizontal line interrupting the cross-hatched first block, and the extent of the cross-hatching indicates the 1 in 40 confidence limits ( 2 or $2.5 \%$ probability value).

FIG. 7. The effect of corticotrophin on the response to a standard meal. The mean of the control values is represented by the horizontal line interrupting the cross-hatched first block, and the extent of the cross-hatching indicates the 1 in 40 confidence limits ( 2 or $2.5 \%$ probability value).

FIG. 8. The effect of hydrocortisone (H.C.) on the pancreatic response to a continuous infusion of secretin. A typical experiment (9 March 1959).

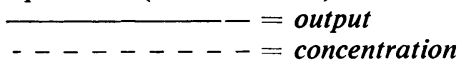




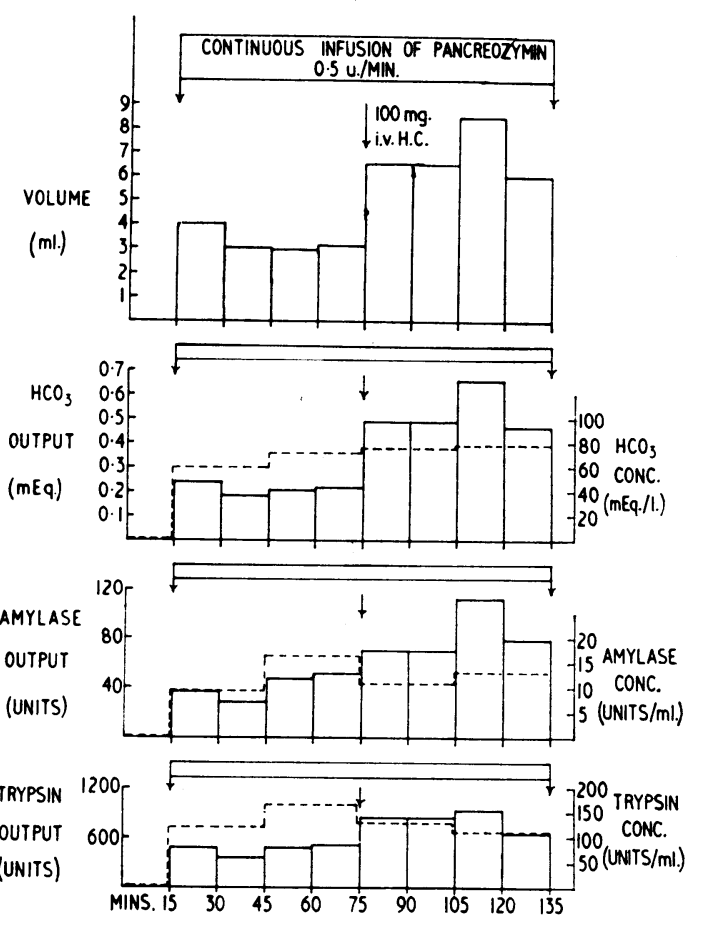

FIG. 9

FIG. 9. The effect of hydrocortisone on the pancreatic response to a continuous infusion of pancreozymin (18 March 1959).

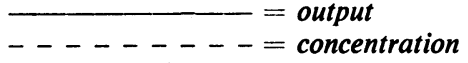

FIG. 10. The effect of hydrocortisone injected 10 minutes beforehand on the pancreatic response to a single injection of secretin (29 April 1960).

S1. 60 units secretin in $1 \mathrm{ml}$. distilled water intravenously.

S2. 60 units secretin in $1 \mathrm{ml}$. distilled water intravenously.

H. $100 \mathrm{mg}$. hydrocortisone hemisuccinate sodium in $1 \mathrm{ml}$. distilled water intravenously.

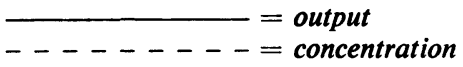

FIG. 11. The effect of hydrocortisone injected 15 minutes beforehand on the pancreatic response to a single injection of pancreozymin (4 May 1960).

P1. 100 units pancreozymin in $3 \mathrm{ml}$. distilled water intravenously.

P2. 100 units pancreozymin in $3 \mathrm{ml}$. distilled water intravenously.

H. $100 \mathrm{mg}$. hydrocortisone hemisuccinate sodium in $3 \mathrm{ml}$. distilled water intravenously.

$$
\begin{aligned}
& - \text { output } \\
& -\ldots+\ldots-\ldots \text { concentration }
\end{aligned}
$$

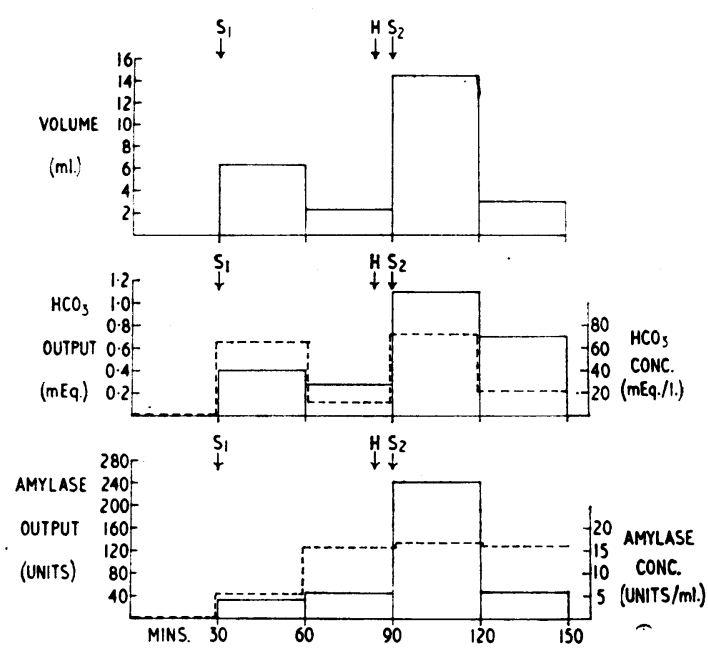

FIG. 10
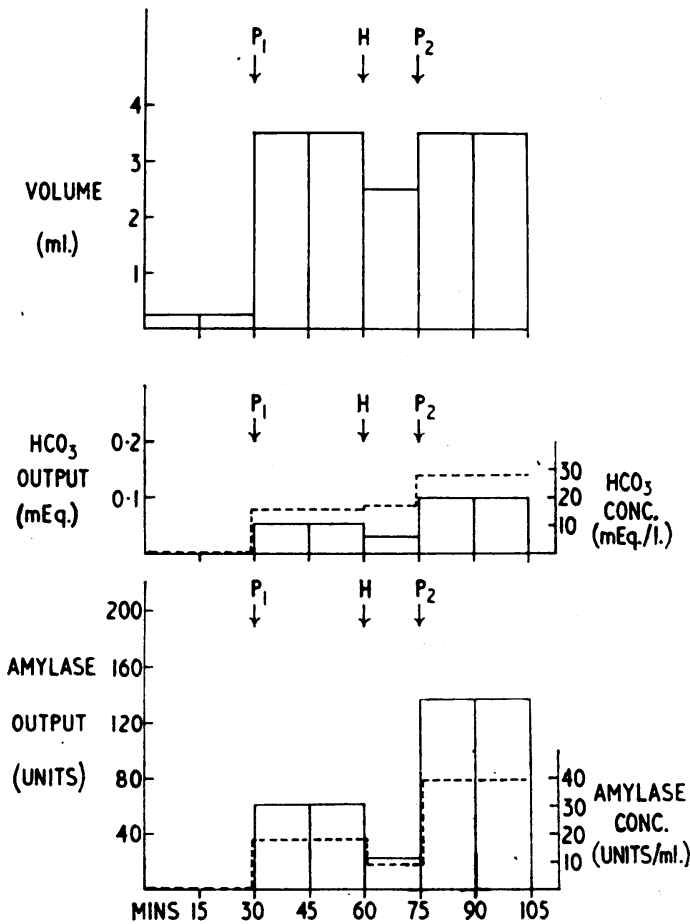

FIG. 11 
the Edinburgh Gastrointestinal Unit we have noted that profound depression of gastric secretion may accompany the prolonged administration of corticotrophin to patients (Crean, 1961) although the effect is unpredictable in the individual subject. Hirschowitz (1956) reported similar depression of gastric secretion with dramatic clinical sequelae in volunteer human subjects infused with corticotrophin. It is only possible to speculate on the significance and mechanism of the depressed secretory response of exocrine glands after the administration of corticotrophin, as the available preparations are crude with variable potency and, possibly, of variable chemical constituency. On the one hand, corticotrophin has been shown capable of producing acinar ectasia and fat necrosis (Carone and Liebow, 1957) and, on the other, hypophysectomy may result in atrophy of the pancreas with repair on the subsequent administration of corticotrophin (Patterson, Dingman, Shwachman, and Thorn, 1954; Kinash and Haist, 1954).

There were striking differences in the effect of cortisone and hydrocortisone upon bicarbonate and the enzymes. In acute experiments the concentration and output of bicarbonate were usually raised whereas prolonged administration of hormones appeared to depress the bicarbonate response, as noted by previous workers. But in both acute and chronic experiments the effect of cortisone and hydrocortisone was essentially to increase the concentrations and outputs of the enzymes although the relative resistance of the secretion of lipase to these influences is notable. The difference in the bicarbonate responses in acute and chronic experiments is as yet inexplicable, especially as structural hyperplasia in the pancreas of experimental animals given cortisone has been found to affect both the epithelium of the ducts (Bencosme and Lazarus, 1956) and acinar cells (Sesso and Oliverio, 1959). At whatever site the electrolytes and enzymes of pancreatic secretion are respectively produced, both may be affected.

It has been postulated (Green, 1941) that hormones act by participating in, or specifically affecting, enzyme systems. It may be that the enzyme systems involved in the intracellular production of exocrine secretions are similar in the different glands of the alimentary tract. Thus studies with thiadiazole compounds have suggested that carbonic anhydrase plays a part in both gastric and pancreatic secretion (Davies, 1951; Birnbaum and Hollander, 1953). The immediate effect of steroids upon the intracellular enzymes could result in augmenting the secretory output, while the cumulative effects of prolonged administration may be exerted through the structural hyperplasia previously reported. It was found that the action of a single injection appeared within five minutes and was never prolonged beyond one hour. Furthermore, the effect was so transient that if it was given $\mathbf{3 0}$ minutes or more before the injection of hormones which stimulate the pancreas no effect could be discerned. I have also noted similar characteristics in the effect of steroids on gastric secretion in dogs.

I wish to thank Mr. W. Forshall, of the Biochemistry Laboratory of the Edinburgh Northern Hospitals Group, for most of the biochemical estimations, and also the Director, Dr. L. Tompsett; Dr. E. Morton, of Boots Pure Drug Co. Ltd., for supplying part of the secretin and pancreozymin; Mr. D. Wright, of the Department of Medicine, for the diagrams; and Mr. S. A. Sklaroff for help with statistics.

Part of the work was supported by a grant from the Scottish Hospital Endowments Research Trust.

\section{REFERENCES}

Bencosme, S. A., and Lazarus, S. S. (1956). The pancreas of cortisonetreated rabbits. A.M.A. Arch. Path., 62, 285-295.

Birnbaum, D., and Hollander, F. (1953). Inhibition of pancreatic secretion by the carbonic anhydrase inhibitor, Diamox. Amer. J. Physiol., 174, 191-195.

Carone, F. A., and Liebow, A. A. (1957). Acute pancreatic lesions in patients treated with ACTH and adrenal corticoids. New Engl. J. Med., 257, 690-697.

Crean, G. P. (1961). The influence of corticotrophin and corticosteroids on human gastric secretion. Proc. internat. Congr. Gastroenterol., 1960, Series 31, p. 373, Excerpta Medica Foundation, Amsterdam.

Davies, R. E. (1951). The mechanism of hydrochloric acid production by the stomach. Biol. Rev., 26, 87-120.

Dreiling, D. A., and Janowitz, H. D. (1959). The secretion of electrolytes by the human pancreas. The effect of Diamox, ACTH, and disease. Amer. J. dig. Dis., n.s. 4, 137-144.

$\longrightarrow,-$, and Rolbin, H. (1958). Effect of ACTH and adrenocortical steroids on external pancreatic secretion in man. New Engl. J. Med., 258, 603-605.

Gowenlock, A. H. (1953). The estimation of tryptic activity in duodenal contents. Biochem. J., 53, 274-277.

Green, D. E. (1941). Enzymes and trace substances. Advanc. Enzymol., 1, 177-198.

Hayano, M., and Dorfman, R. I. (1951). Studies on the inhibition of various enzymes by steroids. Ann. N.Y. Acad. Sci., 54, 608-618.

Hirschowitz, B. (1956). Proceedings of the Gastroenterology Research Group. Gastroenterology, 31, 419-421.

Kinash, B., and Haist, R. E. (1954). Effect of ACTH and of cortisone on islets of Langerhans and the pancreas in intact and hypophysectomized rats. Amer. J. Physiol., 178, 441-444.

Lagerlöf, H. O. (1942). Pancreatic function and pancreatic disease studied by means of secretin. Acta med. scand., Suppl. 128.

Patterson, P. R., Dingman, J. F., Shwachman, H., and Thorn, G. W. (1954). Choleretic action of cortisone. New Engl.J. Med., 251, 502-508.

Pfeffer, R. B., and Hinton, J. W. (1956). Some relationships between adrenal medullary and cortical substances and exocrine functions of the pancreas in man. Gastroenterology, 31, 746-757.

Sammons, H. G., Frazer, A. C., and Thompson, M. (1956). The estimation of true lipase in small intestinal contents. J. clin. Path., 9, 379-380.

Sesso, A., and Oliverio, L. G. (1959). The anabolic action of cortisone on the exocrine pancreas of the suckling rat. Acta physiol. lat.-amer., 9, 13-23.

Umbreit, W. W. (1951). The influence of adrenalectomy and cortisone treatment on enzymatic reactions in rat tissues. Ann. N.Y. Acad. Sci., 54, 569-574. 